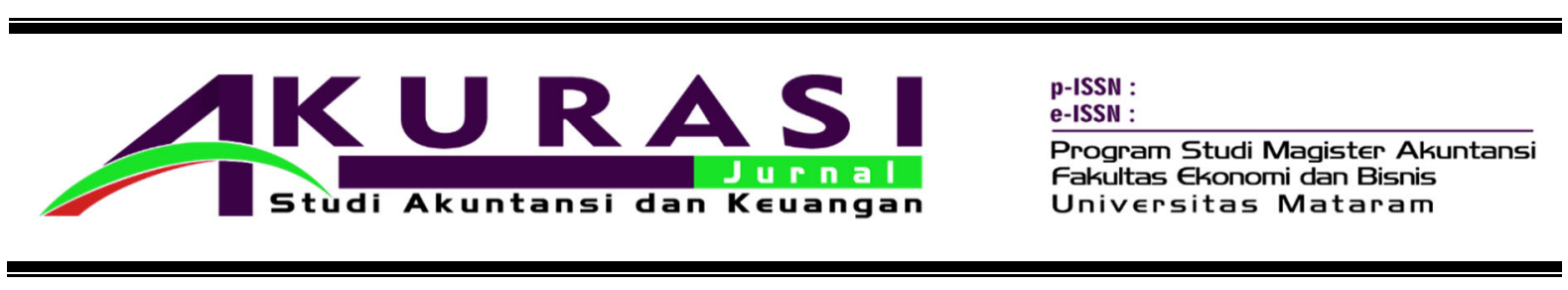

\title{
ANALISIS PERMASALAHAN DALAM PELAPORAN PERTANGGUNGJAWABAN REALISASI PELAKSANAAN APBDES PADA PEMERINTAH KABUPATEN LOMBOK TENGAH
}

\author{
Ana Fatmawati \\ Dinas Pariwisata dan Kebudayaan Kabupaten Lombok Tengah \\ anafatmawati19@yahoo.co.id \\ INFORMASI ARTIKEL \\ Article history: \\ Dikirim tanggal: date \\ Revisi pertama tanggal: date \\ Diterima tanggal: date \\ Tersedia online tanggal $\mathrm{dd} / \mathrm{mm} / \mathrm{yyyy}$

\begin{abstract}
ABSTRAK
Penelitian ini bertujuan untuk menganalisis faktor-faktor yang menjadi kelemahan Laporan Pertanggungjawaban Realisasi Pelaksanaan APBDes pada Pemerintah Kabupaten Lombok Tengah. Metode kualitatif deskriptif dengan pendekatan studi kasus digunakan dalam penelitian ini. Hasil penelitian mengungkapkan bahwa proses penyampaian laporan Pertanggungjawaban Realisasi Pelaksanaan APBDes sering terlambat, regulasi yang sering berubah, pengawasan yang belum optimal oleh Pemerintah Daerah, BPD dan masyarakat serta kelemahan sumber daya manusia dalam pengelolaan keuangan. Implikasi penelitian ini menegaskan bahwa asimetri informasi dapat terjadi akibat penyampaian informasi yang tidak utuh, dan peraturan yang banyak belum menjamin proses pertanggungjawaban yang optimal. Pemerintah Daerah harus meningkatkan pengawasan, melakukan pelatihan, dan sosialisasi mengenai pengelolaan keuangan desa. Pemerintah Daerah dapat menyarankan kepada Pemerintah Pusat tentang pentingnya Standar Akuntansi Pemerintah Desa sebagai pedoman pengelolaan keuangan desa serta mereviu tupoksi Organisasi
\end{abstract} \\ Perangkat Daerah (OPD) yang terlibat dalam pengelolaan keuangan desa.
}

Kata Kunci: Laporan Pertanggungjawaban Realisasi Pelaksanaan APBDes, regulasi, pengawasan, kompetensi SDM, standar akuntansi pemerintah desa.

\begin{abstract}
This study aims to analyze the factors that are the weaknesses of the APBDes Implementation Realization Responsibility Report in Central Lombok Regency Government. Descriptive qualitative methods with a case study approach were used in this study. The results of the study revealed that the process of submitting reports on Realization of the Implementation of the Regional Budget was often late, regulations that often changed, supervision that was not optimal by the Regional Government, BPD and the community and weaknesses in human resources in financial management. The implication of this study confirms that information asymmetry can occur due to the delivery of non-intact information, and many regulations do not guarantee an optimal process of accountability. Local governments must increase supervision, conduct training, and disseminate information on village financial management. The Local Government can recommend to the Central Government on the importance of the Village Government Accounting Standards as a guideline for village financial management and to review the tasks and functions of Regional Work Organizations (OPD) involved in village financial management.
\end{abstract}

Keywords: Village Budget Implementation Realization Accountability Report, regulation, monitoring, Human Resources competency, Village government accounting standard. 


\section{Pendahuluan}

Isu peningkatan dana desa diiringi dengan peningkatan penyalahgunaan dana desa sebagaimana dinyatakan oleh Komisioner Komisi Pemberantasan Korupsi (KPK) bahwa laporan penyalahgunaan dana desa sangat tinggi. Sampai akhir 2016 saja, KPK menerima 300 laporan masyarakat soal dugaan penyalahgunaan dana desa. Begitu juga hasil kajian Indonesia Corruption Watch (ICW). Dalam trend penanganan kasus korupsi 2016, kasus penyimpangan dana desa mengalami peningkatan yang cukup tinggi dan berada di urutan ketiga kasus yang paling banyak ditangani oleh aparat penegak hukum (www.pressreader.com).

Kejaksanaan Negeri Praya Kabupaten Lombok Tengah mencatat bahwa ada puluhan kasus pemerintah desa yang sudah ditangani sejak tahun 2014 yang berkaitan dengan keuangan desa (www.radarlombok.co.id). Ada beberapa faktor yang membuat para pelaku bisa begitu mudah menyelewengkan dana desa. Pertama, monopoli anggaran dimana dominasi penyelenggara desa dalam penyusunan dan pengelolaan anggaran desa masih sangat besar. Kedua, kemauan dan kemampuan masyarakat berpartisipasi dalam perencanaan dan pengawasan masih lemah. Ketiga, tekanan struktur. Pelaku korupsi dana desa bukan hanya perangkat desa. Dalam beberapa kasus, perangkat kecamatan pun turut terlibat. Mereka biasanya menggunakan kewenangan memverifikasi anggaran, rencana pembangunan jangka menengah desa, dan laporan pertanggungjawaban untuk mendapat setoran atau tanda terima kasih dari penyelenggara desa. Selain itu, ada pula kasus korupsi dana desa yang terjadi karena faktor teknis. Para penyelenggara desa tidak memiliki rencana melakukan penyelewengan. Mereka terjebak korupsi karena tidak memahami aturan dan prosedur penganggaran ataupun penggunaan anggaran. Korupsi dana desa menyebabkan hilang atau berkurangnya modal untuk meningkatkan kesejahteraan masyarakat (www.pressreader.com).

Beberapa argumentasi teori yang digunakan untuk menjustifikasi fenomena dalam penelitian ini. Agency Theory yang digunakan untuk menjustifikasi hubungan kontraktual antara pemerintah, masyarakat desa sebagai principal dengan kepala desa dan perangkatnya sebagai agen. Teori Regulasi digunakan untuk melihat peran pemerintah dalam mengatur ketentuan-ketentuan yang harus dilakukan pemerintah desa dalam pertanggungjawaban keuangan desa. Ketentuan diperlukan agar semua (pemakai dan penyaji) mendapatkan informasi yang sama dan seimbang. Untuk melihat juga seberapa jauh peraturan yang telah dibuat berfungsi optimal dalam pelaksanaan pembuatan Laporan Realisasi Pelaksanaan APBDes. Selain itu Good Governance yang diartikan sebagai mekanisme, praktik dan tata cara pemerintahan dan warga mengatur sumber daya serta memecahkan masalah masalah publik digunakan untuk melihat pengelolaan keuangan desa dengan membandingkan dengan prinsip-prinsip yang terdapat di dalam Good Governance.

Beberapa studi terdahulu yang berkaitan tentang akuntabilitas pemerintah desa telah dilakukan oleh Subroto (2009), Sulimin (2015), Farida (2015), Novitasari (2016), Lestari dkk (2014) yang mengemukakan pengelolaan keuangan desa yang responsif, transparan dan akuntabel. Pengelolaan keuangan desa ini harus seimbang dengan pelaporan pertanggungjawaban pelaksanaan yang transparan dan akuntabel dengan cara melakukan pelaporan secara periodik pada pemerintahan tingkat diatasnya. Dalam hal pertanggungjawaban administrasi keuangan kompetensi sumber daya manusia pengelola merupakan kendala utama, sehingga masih memerlukan pendampingan dari aparat pemerintah daerah guna penyesuaian perubahan aturan setiap tahun. Kinerja perangkat desa berpengaruh dalam pengelolaan keuangan yang sesuai dengan undang-undang nomor 6 tahun 2014 (Abidin, 2015). Potensi Fraud tidak dapat dihindari dalam pengelolaan keuangan desa yang dimulai dari proses perencanaan, implementasi dan pelaporan baik dari sisi regulasi, tata kelola, pengawasan, dan sumber daya manusia. Potensi 
berkembangnya fraud dapat ditekan dengan melakukan beberapa strategi anti fraud seperti menerapkan e-budgeting pada keuangan desa, peningkatan kompetensi SDM pengelola, pendamping keuangan desa dan pengawasan yang dilakukan secara bersinambungan (Seputro dkk, 2014; Budiarjo, 2017). Sistem pengendalian intern, kompetensi aparatur, dan moralitas ternyata memberikan pengaruh yang sigfnifikan terhadap pencegahan fraud dalam pengelolaan keuangan desa (Atmadja dkk, 2017). Hal ini dikarenakan bahwa segala jenis tindakan kecurangan dalam keuangan di suatu organisasi/pemerintahan dapat dicegah melalui sistem pengendalian internal yang memadai. Moralitas berhasil memoderasi pengaruh kompetensi aparatur dan sistem pengendalian internal terhadap pencegahan fraud pada pengelolaan keuangan desa. Hal ini diakibatkan karena kompetensi atau kemampuan seseorang dalam mengelola keuangan sering disalahgunakan untuk melakukan kecurangan tanpa didampingi dengan moralitas yang baik, namun moralitas yang baik dan kompetensi aparatur yang memadai juga harus didukung oleh sistem pengendalian internal yang handal sehingga mampu mencegah fraud dalam pengelolaan keuangan desa.

Penelitian ini mengekplorasi fenomena pengelolaan APBDes yang terjadi di Pemerintah Kabupaten Lombok Tengah untuk mengetahui proses pertanggungjawaban laporan keuangan desa. Tujuan penelitian ini adalah untuk mengkaji dan menganalisis faktor-faktor yang menjadi permasalahan dalam Laporan Pertanggungjawaban Realisasi Pelaksanaan APBDes pada Pemerintah Kabupaten Lombok sehingga dapat berkontribusi memberikan solusi untuk melakukan pencegahan penyalahgunaan dana desa.

\section{Kerangka Teoretis}

Agency Theory mengargumentasikan adanya hubungan kontraktual antara dua pihak atau lebih yang salah satu pihak disebut prinsipal (principal) yang menyewa pihak lain yang disebut agen (agent) untuk melakukan beberapa jasa atas nama pemilik yang meliputi pendelegasian wewenang (Jensen dan Meckling, 1976). Agency Theory digunakan dalam penelitian ini untuk menjustifikasi hubungan antara principal dengan agent, dimana kelebihan informasi yang dimiliki agen dapat dimanfaatkan untuk melakukan penyimpangan. Dalam pengelolaan keuangan desa, BPD dan masyarakat desa bertindak sebagai principal dan kepala desa dan perangkat desa sebagai agent.

Regulasi merupakan hasil dari tindakan penekanan kelompok yang menghasilkan hukum dan kebijakan untuk mendukung kalangan bisnis serta melindungi konsumen, pekerja, dan lingkungan (Stigler 1971 dalam Nugroho dan Wrihatnolo 2008). Teori Regulasi dalam penelitian ini digunakan untuk melihat peran pemerintah dalam mengatur ketentuan-ketentuan yang harus dilakukan pemerintah desa dalam pengelolaan keuangan desa. Ketentuan diperlukan agar semua pemakai dan penyaji laporan keuangan mendapatkan informasi yang sama dan seimbang.

Pendapatan desa adalah semua penerimaan uang melalui rekening desa yang merupakan hak desa dalam 1 (satu) tahun anggaran yang tidak perlu dibayar kembali oleh desa. Pendapatan desa diklasifikasikan menurut kelompok dan jenis (Permendagri No. 113 Tahun 2014). Pelaporan dan pertanggungjawaban adalah bagian terakhir dari siklus pengelolaan keuangan desa. Laporan pertanggungjawaban pengelolaan keuangan desa merupakan pemenuhan tanggung jawab kepada masyarakat atas pengelolaan keuangan. Pelaporan merupakan salah satu mekanisme untuk mewujudkan untuk mewujudkan dan menjamin akuntabilitas pengelolaan keuangan desa, sebagaimana ditegaskan dalam asas pengelolaan keuangan desa (asas akuntabel). Pengelolaan keuangan desa harus dapat dipertanggungjawabkan dari berbagai aspek: hukum, administrasi, maupun moral sehingga pelaporan keuangan desa menjadi kewajiban pemerintah desa sebagai bagian dari penyelenggaraan pemerintahan desa yang baik. 
Standar akuntansi pemerintah adalah prinsip-prinsip akuntansi yang diterapkan dalam menyusun dan menyajikan Laporan Keuangan Pemerintah yang terdiri atas Laporan Keuangan Pemerintah Pusat (LKPP) dan Laporan Keuangan Pemerintah daerah (LKPD). Berdasarkan Peraturan Pemerintah Nomor 71 Tahun 2010 tentang Standar Akuntansi Pemerintah (SAP), komponen-komponen yang terdapat dalam satu set laporan keuangan berbasis akrual terdiri dari laporan pelaksanaan anggaran (budgetary reports) dan laporan finansial.

\section{Kerangka Pikir Penelitian}

Kerangka pikir penelitian ini sebagaimana disajikan pada gambar 1 yang mengargumentasikan dimulai dari regulasi tentang Laporan Keuangan Desa yang menjadi dasar praktik normatif dalam pertanggungjawaban keuangan desa. Pedoman tersebut adalah Undang-undang Nomor 6 tahun 2014 tentang Desa, Peraturan Menteri Dalam Negeri Nomor 113 Tahun 2014 tentang Pengelolaan Keuangan Desa, Peraturan Bupati Nomor 18 Tahun 2015 tentang Pedoman Pengelolaan Keuangan Desa dan Peraturan Bupati tentang Tata Cara Pembagian, Penyaluran, Penggunaan, Pelaporam dan Penetapan Rincian Dana Desa setiap desa di Kabupaten Lombok Tengah dan Peraturan Bupati tentang Tata Cara Pengalokasian, Penyaluran, Penggunaan, Pelaporan dan Besaran Alokasi Dana Desa dan Dana Bagi Hasil Pajak Daerah dan Retribusi Daerah Setiap Desa di Kabupaten Lombok Tengah.

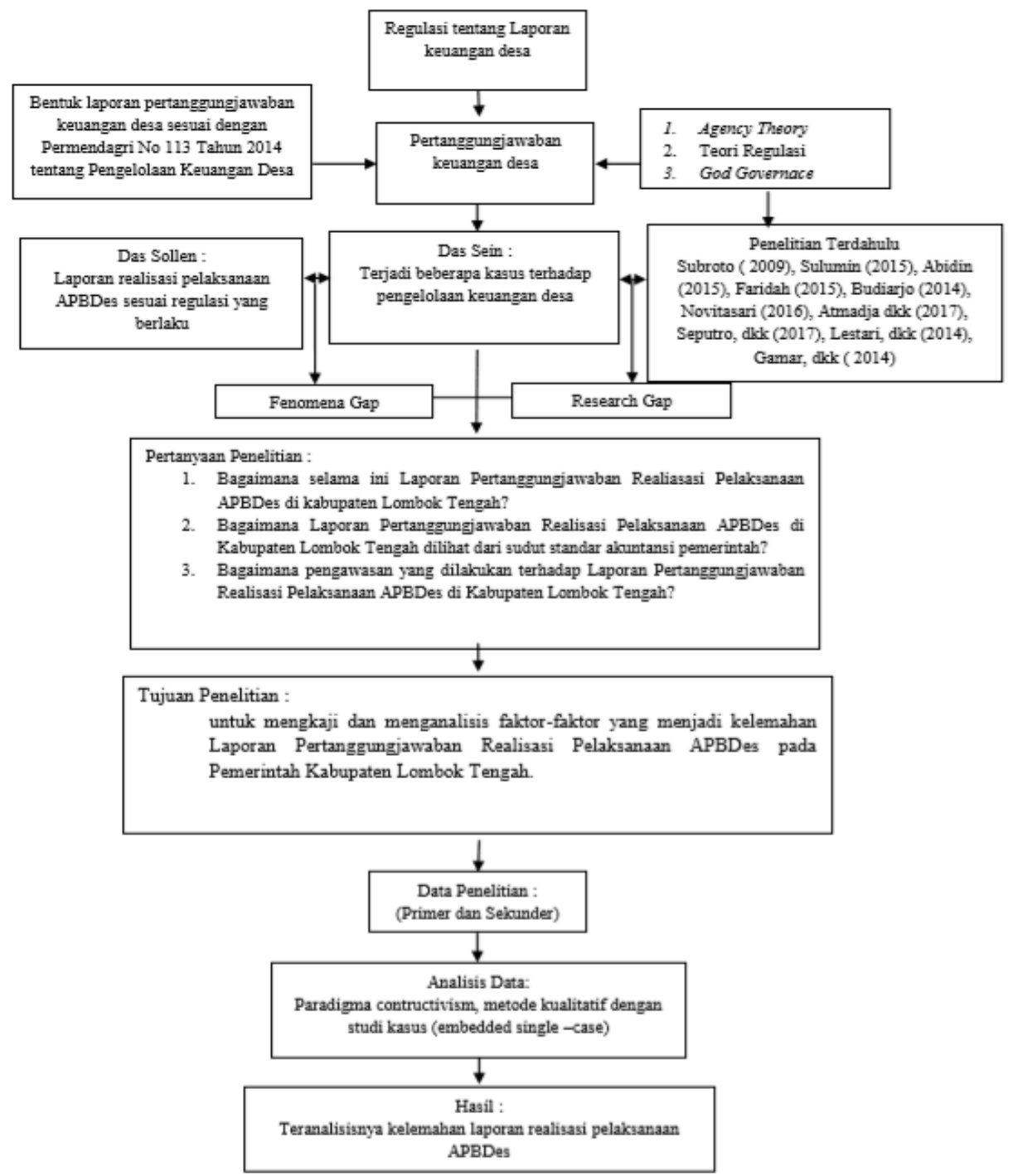

Gambar 1. Kerangka Pikir Penelitian 
Pertanggungjawaban keuangan desa ini dilihat dari Permendagri No. 113/2014 karena peraturan ini yang dijadikan acuan dalam pembuatan laporan pertanggungjawaban keuangan desa. Das Sollen pada penelitian ini menunjukkan bahwa laporan pertanggungjawaban realisasi pelaksanaan APBDes sesuai dengan regulasi yang berlaku, sedangkan Das Sein (realita yang terjadi) menunjukkan adanya beberapa kasus terhadap pengelolaan keuangan desa. Adanya perbedaan antara das sollen dengan das sein inilah maka muncul fenomena gap.

Penelitian ini juga melihat penelitian terdahulu tentang pengelolaan keuangan desa. Dari penelitian terdahulu maka terdapat research gap dengan penelitian yang peneliti lakukan dengan fokus setting lokasi di Pemerintahan Daerah dan Pemerintahan Desa dengan pertimbangan Pemerintahan Daerah yang melakukan pengawasan, pembinaan, evaluasi, monitoring dan pembuatan regulasi terhadap pengelolaan keuangan desa. Pengambilan setting lokasi di Pemerintah Desa karena peneliti merasa harus melihat langsung implemetasi dari kebijakan-kebijakan yang dibuat oleh Pemerintah Daerah dan praktik langsung dari pengelolaan keuangan desa. Dari das sein, fenomena gap dan research gap yang ada maka timbul pertanyaan penelitian (research question). Berdasarkan pertanyaan penelitian ini, maka dirumuskan tujuan dari penelitian yaitu untuk mengetahui faktor-faktor yang menjadi kelemahan Laporan Pertanggungjawaban Realisasi Pelaksanaan APBDes pada Pemerintah Kabupaten Lombok Tengah.

\section{Metode Penelitian}

Jenis metode penelitian kualitatif yang digunakan pada penelitian ini adalah penelitian kualitatif deskriptif dengan pendekatan studi kasus. Menurut Cresswell (2016;4), penelitian kualitatif merupakan metode-metode untuk mengeksplorasi dan memahami makna yang oleh sejumlah individu atau sekelompok orang dianggap berasal dari masalah sosial. Jenis metode penelitian kualitatif yang digunakan pada penelitian ini adalah penelitian kualitatif deskriptif dengan pendekatan studi kasus. Menurut Huberman dan Miles (2002) yang dikutip dalam Kamayanti (2016:75), studi kasus dapat dinyatakan sebagai sebuah pendekatan yang "focus on understanding the dynamics present within single settings". Tipe desain penelitian ini menggunakan embedded single-case karena menggunakan dua unit analisis yaitu Dinas Pemberdayaan Masyarakat Desa Kabupaten Lombok Tengah selaku leading sector dalam pengelolaan keuangan desa dan Desa Tumpak Kecamatan Pujut dengan satu ojek kasus yaitu Laporan Pertanggungjawaban Realisasi Pelaksanaan APBDes.

Data yang digunakan peneliti adalah data sekunder dan data primer. Untuk analisis data peneliti menggunakan paradigma contructivism, metode kualitatif dengan studi kasus (embedded single-case) dan menggunakan analisis tematik. Analisis tematik merupakan proses mengkode informasi, yang dapat menghasilkan daftar tema, model tema atau indikator yang kompleks. Setelah dilakuan analisis data maka akan didapat hasil penelitian yang akan menjawab dari tujuan penelitian, yaitu faktor-faktor yang menjadi kelemahan Laporan Pertanggungjawaban Realisasi Pelaksanaan APBDes pada Pemerintah Kabupaten Lombok Tengah.

Partisipan kunci untuk Pemerintah Daerah ada 4 (empat) orang dan 1 (satu) orang dari pemerintahan desa. Pengumpulan data pada penelitian ini dilakukan melalui wawancara, observasi/studi lapangan, dan dokumen. Dalam penelitian ini untuk menggali informasi secara lebih mendalam, peneliti menggunakan wawancara semistruktur. Tipe wawancara ini juga dapat disebut sebagai wawancara mendalam (in-depth interview). Wawancara mendalam adalah pertemuan tatap muka berulang-ulang antara peneliti dan informan yang diarahkan pada upaya memahami perpektif informan dalam kehidupan mereka, pengalaman atau situasi seperti yang mereka ekspresikan dengan kata-kata mereka 
(Minichiello et al., 1995 dalam Asmony,2015). Pedoman wawancara menggunakan panduan wawancara (protocol interview) yang disajikan pada tabel 1.

Tabel 1. Pedoman Wawancara

\begin{tabular}{|c|c|c|}
\hline No & Informan & Pedoman Wawancara \\
\hline \multirow[t]{6}{*}{1} & \multirow{6}{*}{$\begin{array}{l}\text { Kepala Dinas } \\
\text { Pemberdayaan } \\
\text { Masyarakat dan Desa }\end{array}$} & UU No. 6 Tahun 2014 tentang Desa \\
\hline & & $\begin{array}{l}\text { Besaran Dana Desa dan Alokasi Dana Desa untuk Kabupaten } \\
\text { Lombok Tengah }\end{array}$ \\
\hline & & $\begin{array}{l}\text { Perubahan yang terjadi semenjak UU No. } 6 \text { tahun } 2014 \text { berlaku, baik } \\
\text { perkembangan di desa dan di pemerintahan kabupaten }\end{array}$ \\
\hline & & $\begin{array}{l}\text { Peraturan daerah dan peraturan bupati yang telah terbit untuk } \\
\text { mendukung pelaksanaan undang-undang desa }\end{array}$ \\
\hline & & $\begin{array}{l}\text { Proses pelaksanaan APBDes dan APBDes perubahan secara garis } \\
\text { besar }\end{array}$ \\
\hline & & $\begin{array}{l}\text { Pengendalian dan pengawasan yang dilakukan oleh pihak Kabupaten } \\
\text { terhadap pengelolaan keuangan desa }\end{array}$ \\
\hline \multirow[t]{5}{*}{2} & \multirow[t]{5}{*}{$\begin{array}{l}\text { Kabid Pemerintahan } \\
\text { Desa }\end{array}$} & $\begin{array}{l}\text { Besaran Dana Desa dan Alokasi Dana Desa untuk Kabupaten } \\
\text { Lombok Tengah }\end{array}$ \\
\hline & & Peraturan dalam pengelolaan keuangan desa \\
\hline & & Proses pertanggungjawaban keuangan desa \\
\hline & & $\begin{array}{l}\text { Bentuk laporan pertanggungjawaban keuangan desa dan standar yang } \\
\text { digunakan dalam pembuatan laporan pertanggungjawaban keuangan } \\
\text { desa. }\end{array}$ \\
\hline & & Pengawasan dalam pengelolaan keuangan desa \\
\hline \multirow[t]{3}{*}{3} & \multirow[t]{3}{*}{$\begin{array}{l}\text { Kepala selcsi Keuangan } \\
\text { dan Aset Desa }\end{array}$} & $\begin{array}{l}\text { Proses pertanggungjawaban keuangan desa (pihak-pihak yang } \\
\text { terlibat, waktu penyampaian dan sumber daya manusia yang terlibat } \\
\text { dalam proses pembuatan laporan) }\end{array}$ \\
\hline & & Standar laporan pertanggungjawaban keuangan desa \\
\hline & & Pengawasan dalam pengelolaan keuangan desa \\
\hline \multirow[t]{3}{*}{4} & \multirow{3}{*}{$\begin{array}{l}\text { Kasubag Organisasi } \\
\text { (thn } 2016 \text { menjadi } \\
\text { Kasbid Keuangan dan } \\
\text { Aset Desa) }\end{array}$} & $\begin{array}{l}\text { Proses pertanggungjawaban keuangan desa (pihak-pihak yang } \\
\text { terlibat, waktu penyampaian dan sumber daya manusia yang terlibat } \\
\text { dalam proses pembuatan laporan) }\end{array}$ \\
\hline & & Standar laporan pertanggungjawaban keuangan desa \\
\hline & & Pengawasan dalam pengelolaan keuangan desa \\
\hline \multirow[t]{3}{*}{5} & \multirow[t]{3}{*}{ Aparat Desa } & Proses pertanggungjawaban keuangan desa \\
\hline & & Standar laporan pertanggungjawaban keuangan desa \\
\hline & & Pengawasan dalam pengelolaan keuangan desa \\
\hline
\end{tabular}

Observasi/studi lapangan memungkinkan peneliti merasakan apa yang dirasakan dan dihayati oleh subjek sehingga memungkinkan peneliti juga bertindak sebagai sumber data. Marshall (1996) dalam Sugiyono (2008) menyatakan bahwa "through observation, the researcher learns about behavior and the meaning attached to those behavior". Melalui pengamatan, peneliti belajar tentang perilaku, dan makna dari perilaku tersebut. Posisi peneliti adalah melakukan pengamatan partisipatif, yaitu peneliti turut berpartisipasi dalam kegiatan sehari-hari para partisipan dan diharapkan data yang diperoleh akan lebih lengkap, tajam dan sampai mengetahui pada tingkat makna dari setiap perilaku yang tampak (Sugiyono, 2008).

Dokumen adalah catatan peristiwa yang sudah berlalu yang berbentuk tulisan, gambar atau karya-karya momuntal dari seseorang (Sugiyono, 2008). Adapun dokumen yang dimaksud dalam penelitian ini adalah segala catatan baik berupa catatan dalam kertas (hardcopy), maupun catatan elektronik (softcopy). Peneliti akan melakukan penelaah terhadap dokumen-dokumen yang memilik materi berhubungan dengan penelitian yang dilakukan. Dokumen yang dimaksud yaitu tugas dan fungsi Dinas Pemberdayaan 
Masyarakat Desa Kabupaten Lombok Tengah, Peraturan Daerah dan Peraturan Bupati yang terkait dengan dana desa dan alokasi dana desa, aduan masyarakat terkait pengelolaan dana desa tahun 2015-2016, Laporan Hasil Pemeriksanaan oleh Badan Pemeriksa Keuangan tahun 2016 yang terkait dengan pengelolaan dana desa, laporan pertanggungjawaban dana desa tahun 2015-2016.

Dalam pengujian keabsahan data metode penelitian kualitatif menggunakan validitas internal (credibility) pada aspek nilai kebenaran, pada penerapannya ditinjau dari validitas eksternal (transferability), dan realibilitas (dependability) pada aspek konsistensi, serta obyektivitas (confirmability) pada aspek naturatis (Bungin, 2007;250). Pada penelitian ini, untuk mendapatkan data yang valid akan melakukan uji keabsahan data dengan melakukan uji kredibilitas atau uji derajat kepercayaan (validitas internal) terhadap data hasil penelitian sesuai dengan prosedur uji kredibilitas data dalam penelitian kualitatif. Manfaat dari pengujian ini adalah untuk melaksanakan inkuiri sedemikian rupa sehingga tingkat kepercayaan penemuannya dapat dicapai dan untuk mempertunjukkan derajat kepercayaan hasil-hasil penemuan dengan jalan pembuktian oleh peneliti pada beberapa kenyataan yang sedang diteliti (Moleong, 2005). Pengujian kredibilitas yang dilakukan berupa tringulasi, bahan referensi dan member check.

Prosedur analisis data terdiri dari tiga alur kegiatan yang dilakukan secara bersamaan yaitu reduksi data, penyajian data dan penarikan kesimpulan (Miles dan Huberman, 1994). Langkah-langkah analisa data yang akan dilakukan menurut Creswell (2010), yaitu: 1) mengolah dan mempersiapkan data untuk dianalisis; 2) membaca keseluruhan data; 3 ) menganalisis dengan meng-coding data; 4) mengidentifikasi kategorikategori untuk dianalisa dan memberikan deskripsi terhadap kategori tersebut; 5) menghubungkan kategori yang telah dideskripsikan dengan pendekatan naratif, dengan membentuk tema sesuai dengan kategori yang ada; 6) menginterprestasikan atau memaknai data. Tahapan (1) dan (2) merupakan bagian dari reduksi data, (3), (4), dan (5) adalah bagian dari penyajian data sedangkan (6) adalah penarikan kesimpulan.

\section{Hasil dan Pembahasan}

Berdasarkan hasil studi literatur dan observasi lapangan yang dilakukan pada obyek yang diteliti, dihasilkan beberapa temuan yang dibagi ke dalam 3 (tiga) tema yaitu tema laporan pertanggungjawaban realisasi pelaksanaan APBDes yang ditinjau terhadap waktu penyampaian, regulasi dan sumber daya manusia pada Pemerintah Desa, tema standar akuntansi pemerintah desa dan tema pengawasan.

\section{Tema Laporan Pertanggungjawaban Realisasi Pelaksanaan APBDes}

Waktu Penyampaian Laporan. Temuan terkait Laporan Pertanggungjawaban Realisasi Pelaksanaan APBDes ditinjau dari waktu penyampaian ada 2 (dua) point penting terkait dengan proses Laporan Pertanggungjawaban Realisasi Pelaksanaan APBDes yaitu masalah waktu penyampaian yang seringkali tidak sesuai dengan waktu yang diberikan baik itu yang tertera dalam Permendagri 113/2014 dan Perbup 18/2015 dan keakuratan dari Laporan Pertanggungjawaban Realisasi Pelaksanaan APBDes. Didalam LHP yang dilakukan oleh BPK keterlambatan penyampaian laporan itu menyebabkan sebagian dana desa tidak dapat dievalusi penggunaan dan pemanfaatannya. Pemerintah Desa tidak dapat menyelesaikan Laporan Pertanggungjawaban disebabkan beberapa hal, yaitu keterlibatan BPD dan Tim Pelaksana Kegiatan (TPK). BPD dilibatkan dalam proses pembuatan Laporan Pertanggungjawaban Realisasi Pelaksanaan APBDes, karena penyampaian laporan pertanggujawaban ke Pemerintah Daerah harus dalam bentuk Peraturan Desa. Peraturan Desa ini hanya dapat dibuat apabila telah terjadi kesepakatan dengan BPD. sedangkan TPK terkait dengan bukti-bukti pengeluaran pada saat kegiatan pengelolaan keuangan dilaksanakan. Solusi yang ditawarkan untuk mengatasi masalah keterlambatan 
penyampaian laporan pertanggungjawaban meningkatkan pengawasan dan pemberian sanksi kepada pemerintah desa yang terlambat menyampaikan laporan pertanggungjawaban. BPD melakukan pengawasan pada setiap tahapan pengelolaan keuangan dan lebih selektif dalam menyeleksi anggota TPK (Tim Pelaksana Kegiatan).

Hal lain dalam proses Laporan Pertanggungjawaban ini adalah keakuratan laporan pertanggungjawaban walaupun laporan ini telah ditetapkan dalam Peraturan Desa. Kurang akuratnya laporan pertanggungjawaban ini dapat dilihat dari realisasi yang mempunyai nominal yang sama dengan anggaran. Beberapa penyebab kurang akuratnya laporan ini karena laporan pertanggungjawaban merupakan penggabungan dari beberapa laporan realisasi dana desa dan kekurangan pemahaman aparat desa terhadap pengelolaan keuangan desa. Solusi yang dapat diberikan dalam mengatasi adalah penggunaan aplikasi Siskuedes dalam proses pengelolaan keuangan desa sehingga dapat diawasai penggunaannnya.

Regulasi. Setiap tahun Pemerintah Pusat mengeluarkan regulasi untuk mengganti regulasi di tahun sebelumnya. Perubahan ini seringkali terjadi karena adanya perubahan nominal dana desa, prioritas penggunaan dana desa dan mekanisme pencairan. Dalam pengelolaan dana desa, ada 3 (tiga) kementerian yang terlibat dimana masing-masing kementerian ini akan mengeluarkan peraturan menteri sesuai dengan kewenangan yang diberikan. Kementerian keuangan terkait dengan nominal dana yang diberikan dan mekanisme pencairan, Kemendes terkait dengan prioritas penggunanaan dana desa dan Kemendagri terkait dengan kelembagaan pemerintahan desa. Dampak dari masalah ini pemerintah daerah harus melakukan revisi terhadap Perbup dan Perda yang dibuat agar tidak bertentangan dengan peraturan diatasnya, dalam membuat dan merevisi Perbup dan Perda pemerintah daerah harus melihat beberapa Peraturan Menteri.

Solusi yang ditawarkan dalam menangani penyebab dan dampak yang berhubungan dengan regulasi adalah dibentuknya Tim Pengendali atau Tim Koordinasi dibawah salah satu kementerian dan tetap melakukan koordinasi antara 3 (tiga) kementerian. Untuk mengatasi kesulitan yang dialami Pemerintah Desa dalam memahami peraturan yang ada, maka Pemerintah Daerah melakukan sosialisasi terkait dengan revisi Peraturan yang dilakukan.

Sumber Daya Manusia Pada Pemerintah Desa. Dalam pembuatan Laporan Pertanggungjawaban Realisasi Pelaksanaan APBDes sangat tergantung dari kompetensi yang dimiliki sumber daya manusia yang ada. Penelitian ini melihat sumber daya manusia pada Pemerintah Desa di Kabupaten Lombok Tengah masih kurang, baik itu dalam menggunakan aplikasi program komputer dan pemahaman aparat desa terhadap pengelolaan keuangan desa. Pelatihan yang diberikan oleh Dinas PMD masih kurang untuk meningkatkan pemahaman aparat terhadap pengelolaan keuangan desa, karena hanya dilakukan 1 (satu) kali dalam setahun. Hal ini berdampak terhadap kualitas laporan pertanggungjawaban yang dibuat oleh aparat desa kurang akurat yang dapat dilihat dari nominal realisasi anggaran yang bernilai sama dengan nominal pada anggaran. Solusi yang ditawarkan untuk mengatasi hal ini adalah Dinas PMD meningkatkan jumlah pelatihan dan aparat desa tetap melakukan koordinasi dengan konsultasi dengan pihak Dinas PMD terkait dengan pengelolaan keuangan desa.

\section{Tema Standar Akuntansi Pemerintah Desa}

Dengan semakin besarnya dana yang dikelola oleh Pemerintah Desa, maka diperlukan Standar Akuntansi Pemerintah Desa untuk pelaporan pertanggungjawaban yang dibuat oleh Pemerintah Desa. Laporan pertanggungjawaban yang dibuat oleh Pemerintah Desa mengacu pada Permendagri 113/2014 tentang Pengelolaan Keuangan Desa, dianggap belum cukup mencerminkan kondisi keuangan Pemerintah Desa karena dianggap hanya mencerminkan angka realisasi dan anggaran dari APBDes. Pemerintah Desa merupakan 
entitas pelaporan dimana laporan pertanggungjawabannya harus diaudit oleh BPK. Solusi yang ditawarkan untuk menangani masalah ini dibuatkan standar akuntansi pemerintah desa yang disusun dengan pendekatan peraturan yang telah ada sebelumnya dengan beberapa penyempurnaan yang disesuaikan dengan strandar akuntansi pemerintah serta memperhatikan kemampuan/kondisi riil pada pemerintah desa.

Standar akuntansi pemerintah desa yang telah disusun oleh Komite Standar Akuntansi Pemerintah (KSAP) yang independen dan ditetapkan dengan Peraturan Pemerintah setelah terlebih dahulu mendapat pertimbangan dari Badan Pemeriksa Keuangan. Penyusunan SAPDesa dilakukan oleh KSAP melalui proses baku penyusunan (due process). Proses baku penyusunan SAP tersebut merupakan pertanggungjawaban profesional KSAP. Tahun 2017 KSAP telah berhasil merampungkan draft Standar Akuntansi Pemerintah Desa (SAPDesa) dan pada tanggal 6 September 2017 telah dilakukan pembahasan final mengenai draft SAPDesa antara BPK dengan KSAP. SAPDesa yang dikembangkan olek KSAP menggunakan basis kas murni yang tidak bermuara pada neraca desa.

\section{Tema Pengawasan Pengelolaan Keuangan Desa.}

Pengawasan pengelolaan keuangan desa dilakukan oleh 3 (tiga) pihak, yaitu Pemerintah Daerah, BPD (Badan Permusyawaratan Desa) dan Masyarakat. Kurang optimalnya pengawasan yang dilakukan oleh Pemerintah Daerah disebabkan tidak dilakukannya verifikasi terhadap Laporan Pertanggungjawaban Realisasi Pelaksanaan APBDes. Penyampaian Laporan Pertanggungjawaban hanya digunakan sebagai syarat pencairan berikutnya. Inspektorat yang mempunyai kewajiban melakukan pengawasan dan pembinaan hanya melakukan tugasnya 1 (satu) tahun sekali dan itu pun untuk melakukan 2 (dua) kegiatan sekaligus, yaitu mengawasi kegiatan pengelolaan keuangan yang sedang berlangsung dan kegiatan tahun anggaran sebelumnya. Hal ini berdampak terhadap penggunaan dana desa yang berjalan terus menerus tanpa pengawasan dan kontrol yang memadai dari Pemerintah Daerah. Solusi yang diberikan terhadap permasalahan kurang optimalnya pengawasan yang dilakukan Pemerintah Daerah yaitu melakukan pengawasan melalui Siskuedes dan memperjelas tupoksi Organisasi Perangkat Daerah (OPD) yang melakukan verifikasi terhadap laporan pertanggungjawaban.

Siskeudes adalah aplikasi yang dikembangkan oleh Badan Pengawas Keuangan dan Pembangunan (BPKP) bekerjasama dengan Kementerian Dalam Negeri. Dengan adanya MoU antara Menteri Dalam Negeri dan BPKP pada tanggal 6 November 2015 serta diterbitkannya Surat Edaran Menteri Dalam Negeri tgl 27 November 2015 bahwa Aplikasi Siskeudes sebagai aplikasi tata kelola keuangan desa untuk seluruh desa yang penerapannya secara bertahap mulai tahun 2016. Aplikasi Siskeudes dikembangkan berdasarkan peraturan yaitu Permendagri Nomor 113 tahun 2014 tentang Pengelolaan Keuangan Desa. Selain memiliki tampilan yang mudah digunakan, aplikasi berbasis komputerisasi ini juga dilengkapi dengan petunjuk pelaksanaan implementasi maupun manual aplikasi, mengingat penggunanya memiliki rentang kemampuan yang berbedabeda. Aplikasi siskeudes ini juga dibangun dengan built-in internal control sehingga kesalahan-kesalahan yang terjadi juga dapat diminimalisasi.

Luaran dari aplikasi Siskeudes antara lain, dokumen Perencanaan berupa Rencana Pembangunan Jangka Menengah Desa (RPJM Desa) dan Rencana Kerja Pembangunan Desa (RKP Desa), Dokumen Penganggaran berupa Anggaran Pendapatan dan Belanja Desa (APB Desa), Rincian Anggaran Pendapatan, Rincian Anggaran Belanja (RAB). Dokumen penatausahaan juga dihasilkan dari luaran aplikasi Siskeudes seperti Buku Kas Umum, Buku Bank, Buku Pajak, Buku Rincian Pendapatan, Buku Rincian Pembiayaan, Buku Kas Pembantu Kegiatan, dan bukti transaksi), Laporan-laporan berupa Laporan Realisasi APB Desa, Laporan Kekayaan Milik Desa, Laporan Realisasi per Sumber Dana, dan laporan 
kompilasi tingkat kabupaten/kota, baik laporan kompilasi Dana Desa yang menjadi syarat pencairan Dana Desa maupun laporan kompilasi realisasi pertanggungjawaban pelaksanaan APBDes yang menjadi lampiran Laporan Keuangan Pemerintah Daerah.

Tahun 2017 Pemerintah Lombok Tengah telah mewajibkan pemerintah desa untuk menggunakan aplikasi Siskuedes dalam pengelolaan keuangan desa, sehingga mulai dari perencanaan, pelaksanaan hingga pelaporan keuangan di masing-masing desa dapat dipantau. Apabila ada laporan keuangan yang berpotensi mencurigakan maka Pemerintah Daerah dapat terjun langsung ke lapangan untuk verifikasi dan evaluasi. Pengawasan pengelolaan keuangan desa juga dilakukan oleh BPD, yang mempunyai tugas melakukan pengawasan dan penilaian terhadap kinerja dari kepala desa. Namun demikian permasalahannya adalah tidak aktifnya sebagian anggota BPD, sehingga memberikan dampak fungsi BPD sebagai pengawas dan penilai kinerja kepala desa tidak berjalan optimal, sehingga pemerintah desa lebih sering melakukan koordinasi langsung dengan Pemerintah Daerah. Ketidak aktifan anggota BPD ini juga dapat memberikan celah atau peluang kepada aparat pemerintah desa untuk merubah isi dari Berita Kesepakatan antara anggota BPD dengan Kepala Desa, dengan memisahkan antara lembar tanda tangan dengan lembar keputusan. Selain masalah keaktifan anggota BPD, anggota BPD juga merasa tidak dapat independen dalam menjalankan tugasnya karena merasa honornya dibayar oleh Pemerintah Desa.

Ada beberapa solusi yang ditawarkan untuk menangani permasalahan ketidakaktifan dan independensi dari BPD. Pada saat dilakukan pemilihan, masyarakat agar lebih selektif memilih anggota BPD yang merupakan wakil mereka, kemudian Pemerintah Daerah dapat memberikan pelatihan kepada anggota BPD tentang tugas pokok dan fungsinya sebagai lembaga kemasyarakatan didesa, sehingga diharapkan anggota lebih aktif dalam menjalankan dan memahami tupoksinya. Selain pengawasan yang dilakukan oleh Pemerintah daerah dan BPD, masyarakat juga dapat langsung mengawasi pengelolaan keuangan desa secara langsung. Pemerintah Desa dapat menyampaikan jalannya pengelolaan keuangan termasuk pertanggungjawabannya pada media-media informasi, tetapi hal ini jarang dilakukan karena Pemerintah Desa melihat reaksi dari masyarakat yang dianggap seringkali berlebihan. Reaksi berlebihan yang diberikan masyarakat terhadap informasi akan berdampak kurang terbukanya Pemerintah Desa dalam menyampaikan Laporan Pertanggungjawabannya sehingga masyarakat tidak mengetahui isi dari Laporan Pertanggungjawaban. Solusi yang ditawarkan untuk mengatasi masalah ini adalah menyampaikan kepada masyarakat setiap tahapan dalam proses pengelolaan keuangan desa melalui sarana-sarana informasi yang ada seperti papan-papan pengumuman yang tersedia maupun website pemerintah desa yang resmi.

Berkaitan dengan prinsip transparansi, akuntabel dan partisipatif yang merupakan ciri tata kelola pemerintahan yang baik, maka pertanggungjawaban tidak hanya disampaikan kepada pemerintah yang berwenang, tetapi juga harus disampaikan kepada masyarakat sebagai bentuk akuntabilitas publik. Oleh karena itu, penyampaian informasi tentang pengelolaan keuangan desa secara transparan kepada masyarakat desa sangat diperlukan untuk mewujudkan tata kelola dalam pemerintah desa yang baik.

\section{Kesimpulan, Implikasi dan Keterbatasan}

Laporan pertanggungjawaban realisasi pelaksanaan APBDes di Kabupaten Lombok Tengah terkendala dalam penyampaian laporan yang sering melewati batas yang ditentukan dan kurangnya pemahaman aparat desa terhadap peraturan pengelolaan keuangan desa yang berdampak tidak dapat dilakukannya evaluasi terhadap pengelolaan keuangan yang terlambat penyampaiannya. Regulasi yang dikeluarkan untuk pengelolaan keuangan setiap tahun mengalami perubahan, sehingga pemerintah daerah harus melakukan revisi terhadap 
peraturan yang telah dikeluarkan seperti Perbup dan Perda. Sumber daya manusia pada pemerintah desa yang masih kurang kompeten menyebabkan Laporan pertanggungjawaban realisasi pelaksanaan APBDes kurang akurat.

Laporan Pertanggungjawaban Realisasi Pelaksanaan APBDes di Kabupaten Lombok Tengah sesuai dengan peraturan yang berlaku masih mengacu pada Permendagri 113/2014, belum cukup mampu mencerminkan kondisi keuangan Pemerintah Desa karena hanya mencerminkan angka realisasi dan anggaran dari APBDes, sehingga diperlukan Standar Akuntansi Desa sebagai panduan pelaporan pertanggungjawaban yang dibuat oleh Pemerintah Desa. Fungsi pengawasan yang dilakukan terhadap Laporan Pertanggungjawaban Realisasi Pelaksanaan APBDes dilakukan oleh 3 (tiga) pihak yaitu Pemerintah Daerah, BPD dan masyarakat desa dianggap belum optimal. Hal ini karena tidak dilakukannya verifikasi terhadap Laporan Pertanggungjawaban Realisasi Pelaksanaan APBDes oleh Pemerintah Daerah, sehingga penyampaian Laporan Pertanggungjawaban hanya digunakan sebagai syarat pencairan berikutnya. Pengawasan yang dilakukan BPD juga kurang optimal karena tidak aktifnya sebagian anggota BPD dan masalah independensi yang memberi dampak fungsi BPD tidak dapat berjalan sesuai harapan. Peran masyarakat untuk dapat mengawasi pengelolaan keuangan desa secara langsung juga tidak berjalan optimal karena Pemerintah Desa tidak menyampaikan laporan pertanggungjawaban secara langsung kepada masyarakat.

Keterbatasan penelitian ini adalah persoalan yang di amati hanya pada Laporan Pertanggungjawaban Realisasi Pelaksanaan APBDes belum pada pengelolaan keuangan desa secara keseluruhan, sehingga disarankan untuk penelitian selanjutnya untuk mengevaluasi mulai dari perencanaan sampai dengan pertanggungjawaban. Penelitian ini hanya fokus pada Organisasi Perangkat Desa, yaitu Dinas PMD, sedangkan yang terlibat dalam pengelolaan keuangan desa ada 3 OPD, yaitu Dinas PMD, Inspektorat dan BPKAD (Badan Pengelola Keuangan dan Aset Daerah) sehingga ke depan untuk mendapatkan informasi yang lebih mendalam disarankan untuk menggali informasi dari inspketorat dan BPKAD.

\section{Referensi}

Abidin, M. Z. 2015. Tinjauan Atas Pelaksanaan Keuangan Desa Dalam Mendukung Kebijakan Dana Desa. Jurnal Ekonomi \& Kebijakan Publik 6 (1), 61-76.

Akuntansiterapan.com. (2010). Mengupas Seluk Beluk Fraud dan Cara Mengatasinya. https://akuntansiterapan.com/2010/12/22/mengupas-seluk-beluk-fraud-dan-caramengatasinya.

Asmony, Thatok. 2015. Penelitian Kualitatif: Pendekatan Studi Kasus. Mataram: Mataram University Press.

Atmadja, A. T dan K. A. K. Saputra. 2017. Pencegahan Fraud Dalam Pengelolaan keuangan Desa. Jurnal Ilmiah Akuntansi dan Bisnis, 12, 8-20.

Badan Pengawas Keuangan dan Pembangunan (BPKP). 2008. Kode Etik Dan Standar Audit. Pusat Pendidikan dan Pelatihan Pengawasan BPKP.

Badan Pengawas Keuangan dan Pembangunan (BPKP). 2015. Petunjuk Pelaksanaan Bimbingan \& Konsultasi Pengelolaan Keuangan Desa. Deputi Bidang Pengawasan Penyelenggaraan Keuangan Daerah.

Budiarjo. 2014. Tindak pidana korupsi ADD Desa Sei Bemban Kecamatan. Kubu Kabupaten. Kubu Raya Provinsi Kalimatan Barat. Skripsi, Universitas Tanjungpura.

Bungin, B. 2007. Penelitian Kualitatif: Komunikasi, Ekonomi, Kebijakan Publik dan Ilmu. Jakarta: Penerbit Grenada Media Grup.

Creswell, John.W. 2016. Research Design. Pendekatan Kualitatif, Kuantitatif dan Mixed. Yogyakarta: Penerbit Pustaka Pelajar. 
Jensen and Meckling. 1976. The Theory of The Firm: Managerial Behavior, Agency Cost, and Ownership Stucture. Journal of Financial and Economics, 3, 305-360.

Kamayanti, Ari. 2016. Metodologi Penelitian Kualitatif Akuntansi, Pengantar Religiositas Keilmuan. Jakarta: Yayasan Rumah Peneleh.

Keuangandesa.info. 2015. Pelaporan Dan Pertanggungjawaban Pengelolaan Keuangan Desa: http://www.keuangandesa.info/2015/11/pelaporan-dan-pertanggungjawaban.

Lestari, A.K.D., A.T. Atmadja, dan I.M.P. Adiputra. 2014. Membedah Akuntabilitas Praktik Pengelolaan Keuangan Desa Pakraman Kubutambahan, Kecamatan Kubutambahan, Kabupaten Buleleng, Provinsi Bali (Sebuah Studi Interpretif pada Organisasi Publik Non Pemerintahan). e-Journal S1 Ak Universitas Pendidikan Ganesha Jurusan Akuntansi Program S1 2 (1).

Miles, M.B \& A.M. Huberman. 1994. Qualitative Data Analysis. New York: SAGE Publication

Moleong. 2005. Metodologi Kualitatif Edisi Revisi. Bandung: PT Remaja Rosdakarya.

Novitasari, Y.D. 2016. Analisis Pengelolaan Alokasi Dana Desa (ADD) dan Dana Desa (DD) (Studi Kasus di Desa Donomulyo Kecamatan Donomulya Kabupaten Malang). Skripsi, Universitas Muhamadiyah Malang.

Nugroho, Riant dan R. R. Wrihatnolo. 2008. Manajemen Privatisasi. Jakarta: Elex Media Komputindo.

Peraturan Bupati Lombok Tengah Nomor 1.d tahun 2016 Tentang Tata cara pengalokasian, penyaluran, dan besaran Alokasi dana desa setiap desa Kabupaten Lombok Tengah tahun 2016.

Nomor 18 tahun 2015 tentang Pengelolaan Keuangan Desa.

Peraturan Menteri Keuangan Nomor 247/PMK.07/2015 Tahun 2015 tentang Tata Cara pengalokasian, Penyaluran, Penggunaan, Pemantauan dan Evaluasi Dana Desa.

Peraturan Menteri Dalam Negeri Nomor 113 Tahun 2014 tentang Pedoman Pengelolaan keuangan Desa.

Peraturan Pemerintah Nomor 72 tahun 2005 tentang Desa.

Nomor 43 tahun 2014 tentang Keuangan Desa.

Pressreader.com.2017. Korupsi Mengepung Desa. https://www.pressreader.com/indonesia/kompas/ (diakses 19 Juni 2017).

Radarlombok.co.id. 2017. Korupsi Anggaran Desa di Loteng Makin Parah. http://www.radarlombok.co.id/korupsi-anggaran-desa-di-loteng-makin-parah.html (diakses 21 November 2017).

Seputro, H.Y., S.D. Wahyuningsih dan S. Sunrowiyati. 2017. Potensi Fraud Dan Strategi Anti Fraud Pengelolaan Keuangan Desa. Jurnal Penelitian Teori \& Terapan Akuntansi 2 (1), 79-93

Subroto, Agus. 2009. Akuntabilitas Pengelolaan Dana Desa (Studi Kasus Pengelolaan Alokasi Dana Desa di Desa-desa Dalam Wilayah Kecamatan Tlogomulyo Kabupaten Temanggung Tahun 2008. Tesis. Universitas Diponegoro. Semarang.

Sugiyono. 2016. Metode Penelitian Kuantitatif Kualitatif dan R\&B. Bandung : Alfabeta.

Sulimin, H.H. 2015. Pertanggung Jawaban Penggunaan Alokasi Dana Desa Pada Pemerintahan Desa Di Kabupaten Donggala. e-Jurnal Katalogis, 3 (1), 43-53.

Undang Undang Nomor 32 Tahun 2004 tentang Pemerintah Daerah. Nomor 6 Tahun 2014 tentang Desa. 